\title{
Financial Openness and Economic Growth in Côte d'Ivoire: The Total Factor Productivity Channel
}

\author{
Hugues Kouassi Kouadio ${ }^{1} \&$ Landry Lewis Gakpa ${ }^{1}$ \\ ${ }^{1}$ Ecole Nationale Supérieure de Statistique et d'Economie Appliquée (ENSEA-Africa Center of Excellence), \\ Abidjan, Côte d'Ivoire \\ Correspondence: Landry Lewis Gakpa, Ecole Nationale Supérieure de Statistique et d'Economie Appliquée \\ (ENSEA- Africa Center of Excellence), Abidjan, Côte d'Ivoire.
}

Received: September 17, 2020

Accepted: November 4, 2020

Online Published: January 11, 2021

doi:10.5430/ijfr.v12n2p138

URL: https://doi.org/10.5430/ijfr.v12n2p138

Kouadio and Gakpa wish to express their deep appreciation to the Africa Center of Excellence for the financial support to carry out this research.

\begin{abstract}
This study analyses the influence of financial openness on total factor productivity (TFP) in Cote d'Ivoire to examine one of the channels through which financial openness affects economic growth. To this end, the study uses data from the Penn World Table (PWT) 9.1 and the World Bank over the 1984-2018 periods. By using Dynamic Ordinary Least Squares (DOLS) and Fully Modified Ordinary Least Squares (FMOLS) methods, the paper shows that financial openness positively affects total factor productivity in Côte d'Ivoire. Therefore, total factor productivity is one of the channels through which financial openness affects economic growth. This result calls for a series of measures to strengthen the competitiveness of the country to attract a large inflow of foreign capital and to boost the level of the TFP which is an engine of economic growth. Moreover, the results reveal that financial development, macroeconomic stability (as measured by the inflation rate) and domestic investment are important determinants of total factor productivity growth.
\end{abstract}

Keywords: financial openness, total factor productivity, economic growth, Côte d'Ivoire

\section{Introduction}

The contribution of financial openness (Note 1) to economic growth has been investigated in the literature. Most of these studies have focused on direct and indirect channels through which financial openness could stimulate economic growth. Indeed, according to Vanassche (2004), financial openness allows better resource allocation, portfolio diversification and access of domestic firms to foreign funds, translating into higher profitability and growth. Similarly, Bekaert et al. (2005) and Quinn and Toyoda (2008) show that financial liberalization is beneficial for economic growth through its positive effect on the mobilisation of domestic savings and investment, as well as improving resource allocation. In addition, financial openness by removing barriers to the free movement of capital should increase foreign direct investment and promote technology transfer (McLean and Shrestha, 2002). This is consistent with the neoclassical theory which states that financial openness will imply a transfer of capital from capital-intensive to capital-poor countries, thereby promoting economic growth in poor countries through the acceleration of the convergence process (Note 2). Therefore, international financial openness is a relevant instrument for economic growth and development. This is the reason why most developed and developing countries with the technical assistance of the Bretton Woods institutions (Note 3) and the US Treasury (Giraud, 2001; Bénassy-Quéré and Salins, 2005), have opened their capital accounts to take advantage of international financial openness. This development strategy suggested by these institutions aims to increase the mobilization of necessary capital for investment in order to supplement weak domestic capital mobilisation despite internal financial liberalization.

The above listed studies have contributed to the development and enrichment of the theoretical literature, which deals with the relationship between financial openness and economic development. Although this literature seems to agree on the beneficial effects of financial openness, most of the empirical works on the issue lead to ambiguous and controversial results. Indeed, while some researchers find a positive relationship between international financial 
liberalization and economic growth (Vanassche, 2004; Quinn and Toyoda, 2008; Shahbaz et al., 2008; Vithessonthi and Tongurai, 2012; Oyovwi and Eshenake, 2013; De Nicolò and Juvenal, 2014; among many others), others find either a negative relationship between international financial liberalization and economic growth (e.g. Eichengreen and Leblang, 2003; Ahmed, 2011; Ahmed, 2016) or no significant relationship between these two variables (Alfaro et al., 2009; Baltabaev, 2014; Lane and Milesi-Ferretti, 2018).

The lack of consensus in the relationship between financial openness and economic growth in the empirical literature may be due to the weaknesses of empirical strategies (e.g., Mmolainyane and Ahmed, 2015) or to the heterogeneity of samples (Ahmed, 2013). It can also be driven by the focus of most studies that is oriented towards the direct effects of financial openness on economic growth. In fact, very few have attempted to change the direction of the debate to focus on the effects of financial openness on one of the particular transmission channels through which financial openness impacts economic growth, namely the total factor productivity (Note 4) (TFP).

The current paper aims to fill this gap by exploring the effects of financial openness on TFP in Côte d'Ivoire, an upper-middle income African country. The nature of the relationship between financial openness and TFP growth has important welfare implications, especially in the light of recent literature which highlights the role of TFP growth as the main driver of per capita income growth in the long run (Hall and Jones, 1999; Klenow and Rodriguez-Clare, 1997). Although the previous literature has argued that physical and human capital are the main determinants of economic growth, there is a consensus that TFP growth is much more important than factor accumulation (Hall and Jones, 1999).

TFP is the most important channel of economic growth (Bekaert et al., 2011) and is considered as one of the most important variables in macroeconomics, playing a crucial role in both short- and long-term phenomena (Comin et al., 2020). Several research studies have shown that a large part of the differences in economic performance across countries are explained by total factor productivity (TFP) rather than by factor accumulation (Rahman and Inaba, 2020). In addition, Kose et al. (2009) and Rahman and Inaba (2020) have shown that financial openness is associated with higher TFP growth. Bekaert et al. (2011) went even further by showing that the effect of openness to capital flows on TFP growth is more important than its effect on capital growth. Neo-classical models support these results by arguing that the entry of international financial flows causes only a temporary increase in capital and per capita income since in the long run the capital stock is subject to the law of diminishing returns, which limits its magnitude on growth. However, financial openness can improve long-term economic growth provided that these international financial flows influence technological progress (Solow, 1957; De Mello, 1997).

This paper extends the existing literature on financial openness and economic growth through TFP in the following ways. This is a country case-study which allows considering specific factors affecting the transmission of financial openness to the TFP. To the best of our knowledge, single country studies, particularly in sub-Saharan Africa, are scare. Most studies have used panel data techniques that impose perfect homogeneity on the coefficients across countries, assuming that the results could be applied to all countries. This assumption of homogeneity is likely to be violated because of differences between African countries regarding policies aimed at attracting private foreign capital flows and countries' level of economic development (Ahmed, 2013). Therefore, country experience can provide valuable information.

In addition, Côte d'Ivoire is particularly interesting in several respects. Firstly, like most developing countries, this country gives pride of place to foreign private capital flows in its economic growth and poverty reduction strategy. For instance, net foreign direct investment (FDI) flows have increased on average from US \$64.36 million between 1984-1994 to US \$306.55 million over the 1995-2005 period and US \$465.71 million between 2006-2018, reaching US $\$ 1.008$ billion in 2019 (Note 5), i.e. an increase of $2753 \%$ over the period 1984-2018. Although this trend in private capital flows has not been linear due to political and economic crises that have affected the country, it thus appears that net FDI flows to Côte d'Ivoire have increased sharply since the 1980s. Secondly, over the last twenty years (1997-2017), the contribution of TFP to economic growth in Côte d'Ivoire has increased by 2.04 points according to the IMF (2018). The purpose of this paper is to check whether the increase in FDI is associated with the increase in the contribution of TFP to economic growth in Côte d'Ivoire. Thirdly, Côte d'Ivoire belongs to the West African Economic and Monetary Union (WAEMU) (Note 6), a currency union, in which it plays a dominant economic role, contributing about $40 \%$ of the Union's gross domestic product (GDP). Therefore, conducting such a study is crucial not only for this flagship country but also for the whole of West Africa.

Finally, contrary to previous studies, we construct, following Coulibaly, Gakpa and Soumaré (2018), a financial openness variable which combines both equity and debt flows to better capture cross-border private capital flows in the country. The motivation behind the construction of the financial openness index is to ensure that all the different 
financial liberalisation policies implemented to achieve financially open country status are taken into account in the case of Côte d'Ivoire (Caprio et al., 2001, Laeven, 2003; Owusu and Odhiambo, 2013).

The rest of the paper is structured as follows. The section 2 describes the data and methodology mobilized to conduct the study. The empirical results are analysed and discussed in section 3. The study ends with a conclusion highlighting the main findings and policy recommendations.

\section{Methodology}

\subsection{Model Specification}

Our study aims to test whether TFP is one of the channels through which financial openness affects economic growth. Indeed, the literature states that financial openness stimulates productivity growth through specific channels such as technological spillovers, skills acquisition, and greater efficiency due to increased competition, better resource allocation and good corporate and public governance. Therefore, TFP can be modelled as a function of financial openness. For this purpose, we use a specification that is broadly similar to those of Serdaroğlu (2015) and Rahman and Inaba (2020). The model thus specified is as follows

$$
T F P_{-} t=\alpha_{-} 0+\alpha_{-} 1 \text { FinOpen } \_t+\alpha_{-} 2 X_{-} t+\varepsilon_{-} t
$$

With TFP, the total factor productivity, FinOpen ${ }_{t}$, the variable of openness to international capital. $X_{t}$, a set of control variables expected to influence total factor productivity growth, $\varepsilon_{\mathrm{t}}$, the model error term and $t$, the time dimension.

\subsection{Variables and Data}

This section presents the variables and the sources of data.

\subsubsection{The Dependent Variable (TFP)}

To measure TFP in the study, we start from the neoclassical Cobb-Douglas production function as follows:

$$
Y=A K^{\wedge} \alpha(H L)^{\wedge}(1-\alpha)
$$

Where $Y$ denotes aggregate output, $A$ denotes technical progress or total factor productivity, $K$ and $H$, denotes stocks of physical and human capital, respectively, and $L$ is the number of workers. The growth of aggregate output thus depends on the variation in these four factors. To calculate TFP, it is imperative to have time series data on these factors ( $\mathrm{Y}, \mathrm{K}, \mathrm{H}$ and $\mathrm{L}$ ) as well as an estimate of the parameter " $\alpha$ ", which represents the share of physical capital in national output.

Following Rahman and Inaba (2020), we use the TFP from the Penn World Table (PWT) 9.1. The values of the TFP are at constant national prices $(2011=1)$.

\subsubsection{The Variable of Interest (Financial Openness)}

In the literature, financial openness is approximated by several types of indicators. According to Kose et al. (2010), the first empirical studies on capital account opening used measures of legal restrictions (capital controls) on cross-border capital flows. Thus, these studies used a binary measure (de jure measures) that takes the value zero in the absence of restrictions on the external movement of capital, and one when such restrictions exist. On the other hand, others use capital flows or stocks (de facto measures) as a proxy for the degree of capital account liberalization. This type of indicator has been used by Kraay (1998); Makrem (2009); Lane and Ferreti (2007).

In this study, following Coulibaly, Gakpa and Soumaré (2018), we use private capital flows as a proxy for financial openness in Côte d'Ivoire. The financial openness variable thus noted Finopen is approximated by the sum of the ratios of equity and debt flows to GDP. Equity flows are represented by the sum of net foreign direct investment flows (Note 7) and equity portfolio flows (Note 8). Debt flows are the sum of financing raised through bond issues (Note 9), loans from commercial banks and other creditors. The data of the financial openness are taken from the World Bank database.

\subsubsection{Control Variables}

The choice of control variables is built upon the existing empirical literature. These variables were taken from the World Bank's World Development Indicators (WDI) database and the International Country Risk Guide (ICRG) database for the democracy variable. The main variables are described below:

- Rate of inflation (Infl) is approximated by the change in the consumer price index. The inflation is an indicator of macroeconomic stability. It reflects the quality of the economic policies implemented in a country. A negative 
coefficient is expected since the inflation rate is likely to have an adverse effect on the productivity of open economies, since real depreciation is costly (Romer, 1993).

- Domestic credit to the private sector on GDP (Credsp) as a proxy for the financial development. Although several financial development indicators have been used in the empirical literature (for instance, real interest rate or monetary aggregates), domestic credit to the private sector as a percentage of GDP clearly represents the current volume of funds channelled to the private sector. It also appears to be the most appropriate indicator for developing countries like ours because most of the financial development takes place in the banking sector unlike industrialized countries where a significant part of the financial development occurs beyond the banking system. For these reasons, credit to the private sector represents a better proxy for the financial development in a broad sense (Jimborean, 2004). According to Serdaroğlu (2015), the existence of a financial development system in the country could therefore boost total factor productivity; a positive sign is therefore expected.

- Gross fixed capital formation which includes public and private investment, net of direct investment (\% of GDP) (Inv). The impact of this variable is considered here as a proxy for the effect of aggregate capital intensity on per capita productivity (Ondoa, 2013). This variable also captures the level of infrastructure development (Asiedu and Lien, 2011). A positive coefficient is expected, since the literature has shown a positive relationship between investment and productivity (Rahman and Inaba, 2020).

- To appreciate the role of the institutional framework, a measure of democracy is used. Democracy is considered in the literature as a meta-institution, i.e. an institution from which other institutions in a country are born or strengthened (Rodrik, 2000; Acemoglu, Johnson and Robinson, 2005). According to the ICRG's definition, democratic institutions measure how the government responds to its people. This indicator is rated on a scale of 0 to 6, with a high score indicating better quality of democratic institutions. Democracy gives the different actors in society the possibility to exert pressure on the state, or even to sanction the state in case of failure. The principle of democratic accountability makes the state answerable to its citizens for its actions. It has an obligation to be accountable to its citizens for the management of its affairs. A positive sign is therefore expected.

\section{Empirical Results and Discussions}

\subsection{Analysis of Descriptive Statistics and Correlation Coefficients}

The table in Appendix A-1 presents descriptive statistics of the variables over the 1984-2018 periods. The average value of total factor productivity over the study period is 1.09 with a maximum value of 1.21 and a minimum value of 1 . In terms of growth, over the study period, total factor productivity increased by $11 \%$. As for the proxy of financial openness, it represents $1.6 \%$ of GDP with minimum and maximum values of 0.17 and 5.77, respectively. Regarding the control variables, the indicator of institutional quality, namely democracy, shows an average value of nearly 2.55 on a scale of 0 to 6 . Its maximum and minimum values are 1 and 3 respectively. This highlights the weakness of democracy in Côte d'Ivoire. The macroeconomic instability approximated by the inflation rate and measured by the consumer price index shows an average value of $3.8 \%$ with a minimum value of -0.80 and a maximum value of 26.08. Regarding gross fixed capital formation, its average value is around $12.9 \%$ of GDP with minimum and maximum values of $4.70 \%$ and $23.48 \%$ of GDP. Finally, the level of financial development approximated by domestic credit to the private sector averages $21.92 \%$ of GDP. Its minimum and maximum values are $12.45 \%$ and $37.93 \%$ of GDP.

The table in Appendix A-2 presents the matrix of correlation coefficients between the different explanatory variables of the study. Overall, the correlation coefficients between the different variables are all generally low with the exception of the correlation between the financial development and financial openness indicator, which shows a correlation coefficient of the highest (0.61) but less than 0.8 (Note 10). Therefore, we can conclude that there is no significant multicollinearity between the variables in the empirical model.

\subsection{Unit Root Tests}

The modelling of time series requires first examining the degree of integration of each of the variables. This step is necessary to avoid spurious regressions when the variables are not stationary (Granger and Newbold, 1974). It has implications for the estimation of the empirical model because estimation techniques differ according to the classification of variables.

In the case of our study, we examine the stationarity of time series using the Augmented Dickey Fuller (ADF) and Phillips-Perron tests. These tests are well documented in the literature (Note 11). The results of the tests are reported in the Table 1 below. 
Table 1. Results of unit root tests

\begin{tabular}{llllll}
\hline Variables & \multicolumn{2}{l}{ In Level } & \multicolumn{2}{l}{ In First Difference } & Order of integration \\
\cline { 2 - 5 } & ADF & PP & ADF & PP & \\
\hline TFP & -1.023 & -1.023 & $-4.840^{* * *}$ & $-4.876^{* * * *}$ & I $(1)$ \\
\hline Finopen & $-2.965^{* *}$ & $-2.965^{* *}$ & - & - & $\mathrm{I}(0)$ \\
\hline Inv & -1.889 & -1.889 & $-7.888^{* * *}$ & $-7.888^{* * *}$ & $\mathrm{I}(1)$ \\
\hline Infl & $-4.051 * * *$ & $-4.051^{* * *}$ & - & - & $\mathrm{I}(0)$ \\
\hline Credsp & -1.700 & -1.700 & $-4.673^{* * *}$ & $-4.673^{* * *}$ & $\mathrm{I}(1)$ \\
\hline Demo & -1.796 & -1.796 & $-4.197 * * *$ & $-4.197 * * *$ & $\mathrm{I}(1)$ \\
\hline
\end{tabular}

Note: $(* * *),(* *)$, indicate the rejection of the null hypothesis at the $1 \%$ and $5 \%$ threshold.

Source: Authors' calculations

The results show that the variables are either stationary in level $\mathrm{I}(0)$ or stationary in first difference $\mathrm{I}(1)$. The results of the unit root tests therefore show that none of the variables are integrated at an order higher than 1 and that they are not all integrated at the same order, which according to Pesaran, Shin and Smith (2001) presages the existence of a long-term relationship between the variables. In the next section, we test the existence of cointegration among the variables.

\subsection{Analysis of Cointegration}

We use the technique developed by Pesaran, Shin and Smith (2001) to test the existence of a long-term relationship between the variables because it has several advantages. It is more appropriate for testing the existence of long-term relationships in small samples and, unlike the approach of Johansen and Juselius (1990), it allows us to test them between variables with different orders of integration $(\mathrm{I}(1)$ an $\mathrm{I}(0)$ ). The ARDL form of the equations to be estimated is as follows:

$$
\begin{aligned}
& \Delta \text { TFP }_{t}=\mu_{1}+\sum_{i=1}^{m} \beta_{1 i} \Delta T F P_{t-i}+\sum_{i=0}^{p} \beta_{2 i} \Delta \text { Finopen }_{t-i}+\sum_{i=0}^{p} \beta_{3 i} \Delta \text { Inv }_{t-i}+\sum_{i=0}^{p} \beta_{4 i} \Delta \text { Credsp }_{t-i}+ \\
& \quad \sum_{i=0}^{p} \beta_{5 i} \Delta \text { Infl }_{t-i}+\sum_{i=0}^{p} \beta_{6 i} \Delta \text { Demo }_{t-i}+\gamma_{1} \Delta \text { TFP P }_{t-1}+\gamma_{2} \text { Finopen }_{t-1}+\gamma_{3} \text { Inv }_{t-1}+\gamma_{4} \text { Credsp }_{t-1}+ \\
& \gamma_{5} \text { Infl }_{t-1}+\gamma_{6} \text { Demo }_{t-1}+\varepsilon_{t}
\end{aligned}
$$

Where $\Delta$ is the first difference operator; $\mu_{1}$ the constant; $\varepsilon_{t}$ the error term; $p$ is the optimal lag length of the vector autoregressive model VAR (p) from which the error-correction model is derived.

According to the ARDL approach, a long term relationship between the variables of the model exists when the null hypothesis of absence of cointegration $\left(\gamma_{1}=\gamma_{2}=\gamma_{3}=\gamma_{4}=\gamma_{5}=\gamma_{6}=0\right)$ is rejected. This hypothesis is tested through a Fisher test where the calculated value of the statistic is compared to the critical values simulated by Pesaran Shin and Smith (2001). These authors provide two sets of values representing upper and lower bounds respectively. The hypothesis of absence of cointegration is rejected when the calculated value of the Fisher F-statistic is higher than the upper bound. It is not rejected if it is lower than the lower bound, and it is not possible to conclude if it is between the two bounds.

The results of the «bounds test» procedure are presented in Appendix A-3. The asymptotic critical bounds values tabulated by Pesaran et al. (2001) for F-statistics are presented in Appendix A-4. The results from the table show that the Fisher statistic is above the $1 \%$ upper bound for the specification. Therefore, we reject the null of no long-term relationship and conclude that a long-term relationship exists between the different variables in the model.

The next step is to estimate the long-term relationship between financial openness and total factor productivity.

\subsection{Estimation Results and Discussions}

We use the Dynamic Ordinary Least Squares (DOLS) technique to estimate the long-run relationship. This technique is a parametric procedure proposed by Saikkonen (1991) and Stock and Watson (1993) in the case of time series. It consists in including leads and lags of the explanatory variables in the cointegration relationship, to deal with endogeneity and serial correlation of residuals.

To ascertain the robustness of the results, we use the Fully Modified Ordinary Least Squares (FMOLS) technique. 
This is a semi-parametric procedure, initially proposed by Phillips and Hansen (1990) and developed by Phillips (1995). It consists of applying the OLS to a transformed model to orthogonalize the residual of the cointegration relationship with respect to the innovations of the non-stationary variables.

These two methods take into account potential endogeneity of regressors and have good properties on small samples, as in our case.

Table 2 presents the empirical results estimated using the DOLS technique of the long-run relationship between financial openness and total factor productivity after controlling for other macroeconomic variables.

Table 2. Regression results using the DOLS method

\begin{tabular}{lllll}
\hline Variables & Coefficient & Std. Error & t-statistic & Prob. \\
\hline Finopen & 0.0127 & 0.0066 & 1.9270 & 0.0802 \\
\hline Credsp & 0.0051 & 0.0009 & 5.3564 & 0.0002 \\
\hline Infl & -0.0078 & 0.0007 & -11.1823 & 0.0000 \\
\hline Inv & 0.0106 & 0.0006 & 16.0047 & 0.0000 \\
\hline Demo & -0.0173 & 0.0111 & -1.5481 & 0.1499 \\
\hline Constant & 0.8937 & 0.0217 & 41.0208 & 0.0000 \\
\hline R-squared & & 0.963 & & \\
\hline Adjusted R-squared & & 0.896 & & \\
\hline
\end{tabular}

Source: Author's estimate under Eviews 9.0

The adjusted R-squared show that the estimates are very acceptable. Indeed, the specifications explain more than $89 \%$ of the variations in total factor productivity in Côte d'Ivoire.

An examination of the regression results shows that the both DOLS and FMOLS techniques provide similar results (Note 12).

The coefficients of the international capital openness variable are all significant and positive. Indeed, the estimates reveal that a one-point increase in the financial openness indicator is associated with an increase in TFP of around 0.01 points. This positive result is consistent with those obtained by Rahman and Inaba (2020), Serdaroğlu (2015) and Kose et al. (2008). This result also supports that of Bonfglioli (2008) who showed in his study that financial openness has a positive and significant impact on total factor productivity growth and not on capital accumulation or investment. This result, like those of Bekaert et al. (2011), thus reveals that financial openness is an important determinant of total factor productivity growth.

This result thus confirms that openness to international capital flows indirectly stimulates economic growth in Côte d'Ivoire through improvements in total factor productivity. This occurs, as noted by Gehringer (2013), through better and more efficient allocation of resources (Obstfeld, 1994; Acemoglu and Zilibotti, 1997; Edison et al., 2002), as well as through easier access to investment opportunities (Giannett et al. 2002). Furthermore, financial openness may also directly affect factor productivity, for example, by spurring financial development, promoting better corporate governance, or signalling higher quality governments (Rajan and Zingales, 2003). This positive effect of financial openness on productivity could also be explained by the efficiency gains resulting from competition and the transfer of technological and managerial know-how. Moreover, financial openness may result in a reduction or even complete elimination of capital constraints, permitting the economy to engage in a more productive investment (Acemoglu et al., 2006; Acemoglu and Zilibotti, 1997).

Therefore, these results complement previous studies insofar as we use a broader and more up-to-date indicator of financial openness that captures all the different capital flows and encompasses all financial liberalisation policies implemented in Côte d'Ivoire.

In view of these results, and with a view to enabling Côte d'Ivoire, the locomotive of the WAEMU, to better benefit from the positive effects of international financial liberalisation, we believe that economic decision-makers should encourage the attraction of foreign capital flows by putting in place more favourable conditions for their entry. 
Concerning the control variables, we find that the coefficient of domestic credit to the private sector is positive and statistically significant at the $1 \%$ threshold. This positive result implies that financial development is favourable to total factor productivity growth in Côte d'Ivoire. This result is consistent with the findings of Rahman and Inaba (2020) and Serdaroğlu (2015). Similarly, domestic investment has a positive influence on total factor productivity. This result corroborates those of Rahman and Inaba (2020).

Macroeconomic stability is captured in the study by the rate of inflation. Low inflation being a sign of macroeconomic stability, a negative sign of the coefficient was therefore expected since a stable macroeconomic environment characterized by low inflation should be conducive to total factor productivity growth. As expected, the inflation rate coefficient shows a significant negative sign. This result is consistent with that obtained by Serdaroğlu (2015).

\section{Conclusion and Implication of Economic Policies}

In this article, we examine the influence of financial openness on total factor productivity in Côte d'Ivoire over the 1984-2018 periods. In this respect, we have constructed an indicator of financial openness that combines both equity and debt flows. The data for this study come from the Penn World Table (PWT) 9.1 database and the World Bank.

From the regression results, it appears that financial openness has a positive and statistically significant effect on total factor productivity which is a powerful growth engine. Thus, TFP turns out to be an indirect transmission channel from financial openness to economic growth. High TFP reflects a high level of technology and means that capital and labour can yield high rates of return while the cost of production remains low.

Moreover, the results provide empirical evidence that domestic credit to the private sector, macroeconomic stability and domestic investment are determinants of total factor productivity.

In view of these results, a number of policy implications can be formulated. Policy makers would benefit from pursuing economic and institutional reforms to make the country a more attractive location for private capital flows. In this regard, openness to international capital flows is proving to be a crucial determinant of aggregate factor productivity.

These reforms could focus on reducing administrative barriers to the movement of inward capital, implementing incentives to attract foreign capital, improving the institutional framework to facilitate transactions and reduce uncertainty, placing an even stronger emphasis on policies to strengthen human capital as educated and healthy people are incentives for capital providers, and finally ensuring a well-functioning financial market, as a well-functioning financial market reduces transaction and information costs.

These are some challenges that policymakers should address to benefit from private capital flows, which are a key driver of total factor productivity growth and hence economic growth. These recommendations are particularly relevant for Côte d'Ivoire since the country's performance in terms of attractiveness of private capital flows is still marginal compared to the world as a whole, i.e. $0.06 \%$ of global and continental FDI flows, i.e. 4 times less than Nigeria and Ghana.

\section{References}

Acemoglu, D., \& Zilibotti, F. (1997). Was Prometeus unbound by chance? Risk, diversification and growth. Journal of Political Economy, 105, 709-752. https://doi.org/10.1086/262091

Acemoglu, D., Aghion, P., \& Zilibotti, F. (2006). Distance to frontier, selection, and economic growth. Journal of the European Economic Association, 4, 37-74. https://doi.org/10.1162/jeea.2006.4.1.37

Acemoglu, D., Johnson, S., \& Robinson, J. A. (2005). Institutions as the fundamental cause of long-run growth. In P. Aghion, \& S. Durlauf (Eds.), Handbook of economic growth. Amsterdam: North-Holland.

Ahmed, A. D. (2011). International financial integration, investment and economic performance in sub-Saharan African countries. Global Economy Journal, 4(5), 1-26. https://doi.org/10.2202/1524-5861.1712

Ahmed, A. D. (2013). Effects of financial liberalization on financial market development and economic performance of the SSA region: an empirical assessment. Economic Modelling, 30, 261-273. https://doi.org/10.1016/j.econmod.2012.09.019

Ahmed, A. D. (2016). Integration of financial markets, financial development and growth: Is Africa different?. Journal of International Financial Markets, Institutions \& Money, 42, 43-59. https://doi.org/10.1016/j.intfin.2016.01.003

Alfaro, L., Kalemli-Ozcan, S., \& Sayek, S. (2009). FDI, productivity and financial development. The World 
Economy, 32(1), 111-135. https://doi.org/10.1111/j.1467-9701.2009.01159.x

Asiedu, E., \& Lien, D. (2011). Democracy, foreign direct investment and natural resources. Journal of International Economics, 84, 99-111. https://doi.org/10.1016/j.jinteco.2010.12.001

Baltabaev, B. (2014). FDI and total factor productivity growth: New Macro-Evidence. The World Economy, 37(2), 311-334. https://doi.org/10.1111/twec.12115

Bekaert, G., Harvey, C. R., \& Lundblad, C. (2011). Financial openness and productivity. World Development, 39(1), 1-19. https://doi.org/10.1016/j.worlddev.2010.06.016

Bénassy-Quéré, A., \& Salins, V. (2005). Impact de l'ouverture financière sur les inégalités internes dans les pays émergents. Document de travail du CEPII, 11.

Bonfglioli, A. (2008). Financial integration, productivity, and capital accumulation. Journal of International Economics, 76(2), 337-355. https://doi.org/10.1016/j.jinteco.2008.08.001

Caprio, G., Honohan, P., \& Stiglitz, J. E. (2001). Financial Liberalization: How Far? How Fast?. Cambridge: Cambridge University Press

Comin, D. A., Javier, Q., Gonzalez, T., Schmitz, G., \& Trigari, A. (2020). Measuring TFP: the role of profits, adjustment costs, and capacity utilization. Working Paper 28008. Nber Working Paper Series.

Coulibaly, S., Gakpa, L., \& Soumare, I. (2018). The Role of Property Rights in the Relationship between Capital Flows and Economic Growth in SSA: Do Natural Resources Endowment and Country Income Level Matter?. African Development Review, 30(1), 112-130. https://doi.org/10.1111/1467-8268.12316

De Mello, L. R. (1997). Foreign direct investment in developing countries and growth: A selective survey. Journal of Development Studies, 34(1), 1-34.https://doi.org/10.1080/00220389708422501

De Nicolò, G., \& Juvenal, L. (2014). Financial integration, globalization, and real activity. Journal of Financial Stability, 10(C), 65-75. https://doi.org/10.1016/j.jfs.2013.04.004

Edison, H. J., Levine, R., Ricci, L. A., \& Sløk, T. M. (2002). International financial integration and economic growth. Journal of International Money and Finance, 21, 749-776. https://doi.org/10.1016/S0261-5606(02)00021-9

Egbetunde, T., \& Akinlo, A. E. (2014). Financial integration and economic growth in Sub-Saharan Africa. Journal of Sustainable Development in Africa, 16(6), 83-96.

Eichengreen, B., \& Leblang, D. (2003). Capital account liberalization and growth: was Mr. Mahathir, right?. International Journal of Finance and Economics, 8(2003), 205-224. https://doi.org/10.1002/ijfe.208

Gehringer, A. (2013). Growth, productivity and capital accumulation: The effects of financial liberalization in the case of European integration. International Review of Economics and Finance, 25, 291-309. https://doi.org/10.1016/j.iref.2012.07.015

Giannetti, M., Guiso, L., Jappelli, T., Padula, M., \& Pagano, M. (2002). Financial market integration, corporate financing and economic growth. European Commission Economic Papers No. 179.

Giraud, A. (2001). La crise indonésienne et le rôle du FMI. Finance et développement, Juin.

Granger, C., \& Newbold, P. (1974). Spurious regressions in econometrics. Journal of Econometrics, 2, 111-120.

Hall, R. E., \& Jones, C. I. (1999). Why do some countries produce so much more output per worker than others?. The Quarterly Journal of Economics, 114(1), 83-116. https://doi.org/10.3386/w6564

IMF. (2018). West African Economic and Monetary Union. March, IMF Country Report, 18/107.

Jimborean, R. (2004). Developpement financier et croissance économique dans les pays en transition. Retrieved from www. ifgtunisia.org/

Johansen, S., \& Juselius, K. (1990). Maximum Likelihood Estimation and Inference on Cointegration - With Applications to Demand for Money. Oxford Bulletin of Economics and Statistics, 52(2), 169-210. https://doi.org/10.1111/j.1468-0084.1990.mp52002003.x

Kao, C., \& Chiang, M. (2000). On the estimation and inference of a cointegrated regression in panel data. Advances in Econometrics, 15, 179-222. https://doi.org/10.1016/S0731-9053(00)15007-8

Klenow, P. J., \& Rodriguez-Clare, A. (1997). The neoclassical revival in growth economics: Has it gone too far?. NBER Macroeconomics Annual, 12, 73-103. 
Kose, M. A., Prasad, E. S., \& Terrones, M. E. (2008). Does openness to international financial flows raise productivity growth?. IMF Working Paper 08/242. International Monetary Fund, Washington.

Kose, M., Ayhan, P. E., Rogoff, K., \& Wei, Sh.-J. (2009). Financial globalization: A reappraisal. IMF Staff Papers, 56, 8-62.

Kose, M., Ayhan, P. E., Rogoff, K., \& Wei, Sh.-J. (2010). Financial globalization and economic policies. In D. Rodrik, \& M. R. Rosenzweig (Eds.), Handbook of development economics (Vol. 5, pp. 4283-4362). North-Holland, Amsterdam.

Kraay, A. (1998). In search of the macroeconomic effects of capital account liberalization. Manuscript, World Bank, Washington, DC.

Laeven, L. (2003). Does Financial Liberalization Reduce Financing Constraints?. Financial Management, 32(1), 5-34. https://doi.org/10.2307/3666202

Lane, P. R., \& Milesi-Ferretti, G. M. (2007). The external wealth of nations mark II: Revised and extended estimates of foreign assets and liabilities, 1970-2004. Journal of International Economics, 73(2), 223-250. https://doi.org/10.1016/j.jinteco.2007.02.003

Lane, P. R., \& Milesi-Ferretti, G. M. (2018). The external wealth of nations revisited: international financial integration in the after- math of the global financial crisis. IMF Economic Review, 66(1), 189-222.

Makrem, B. D. (2009). Relation between financial integration and growth: why is she ambiguous?. MPRA Paper, 12982, January.

McKinnon, R. (1973). Money and capital in economic development. Washington DC, Brookings Institution.

McLean, B., \& Shrestha, S. (2002). International Financial Liberalization and Economic Growth. Research Discussion Paper of Bank of Australia, 3.

Mmolainyane, K. K., \& Ahmed, A. D. (2015). The impact of financial integration in Botswana. Journal of Policy Modeling, 37, 852-874. https://doi.org/10.1016/j.jpolmod.2015.03.015

Montalvo, J. G. (1995). Comparing cointegrating regression estimators: Some additional Monte Carlo results. Economics Letters, 48, 229-234. https://doi.org/10.1016/0165-1765(94)00632-C

Nguyen, Q. N., Pham, T. M., \& Bhar, R. (2014). Foreign direct investment and economic growth during financial liberalization episodes. International Journal of Economics and Finance, 6(8), 91-10. https://doi.org/10.5539/ijef.v6n8p91

Obstfeld, M. (1994). Risk-taking, global diversification, and growth. American Economic Review, 84, 1310-1329. Retrieved from https://www.jstor.org/stable/2117774

Ondoa, H. A. (2013). Gouvernance et croissance économique en Afrique. African Development Review, 25(2), 130-147. https://doi.org/10.1111/j.1467-8268.2013.12020.x

Owusu, E. L., \& Odhiambo, N. (2013). Financial liberalization and economic growth in Ivory Coast: an empirical investigation. Investment Management and Financial Innovations, 10(4-1).

Oyovwi, O. D., \& Eshenake, S. J. (2013). Financial openness and economic growth in Nigeria: a vector error correction approach. An International Multidisciplinary Journal, 7(4), 79-92. https://doi.org/10.4314/afrrev.7i4.6

Pesaran, M. H., Shin, Y., \& Smith, R. J. (2001). Bounds testing approaches to the analysis of level relationships. Journal of Applied Econometrics, 16(3), 289-326. https://doi.org/10.1002/jae.616

Phillips, P. (1995). Fully modified least squares and vector autoregression. Econometrica, 63, 1023-1078. https://doi.org/10.2307/2171721

Phillips, P. C. B., \& Hansen, B. E. (1990). Statistical Inference in Instrumental Variables Regression with I (1) Process. The Review of Economic Studies, 57, 99-125. https://doi.org/10.2307/2297545

Quinn, D. P., \& Toyoda, A. M. (2008). Does Capital Account Liberalization Lead to Economic Growth? An empirical investigation. Review of Financial Studies, 21(3), 1403-1449. https://doi.org/10.1093/rfs/hhn034

Rahman, Md. A.-U., \& Inaba, K. (2020). Financial integration and total factor productivity: in consideration of different capital controls and foreign direct investment. Journal of Economic Structures, 9(25), 2-20. https://doi.org/10.1186/s40008-020-00201-9 
Rajan, R. G., \& Zingales, L. (2003). The great reversals: The politics of financial development in the twentieth century. Journal of Financial Economics, 69, 5-50.

Reinhart, C. M., \& Reinhart, V. R. (2008). Capital flow bonanzas: an encompassing view of the past and present. NBER Working paper, 14321.

Rodrik, D. (2000). Comments on Trade, Growth and Poverty by Dollar et Kraay. Mimeo, Cambridge MA, Harvard University, October.

Romer, P. M. (1993). Openness and inflation: theory and evidence. Quarterly Journal of Economics, 108(4), 870-903.

Saikkonen, P. (1991). Asymptotically Efficient Estimation of Cointegration Regressions. Econometric Theory, 7, 1-21. https://doi.org/10.1017/S0266466600004217

Serdaroğlu, T. (2015). Financial Openness and Total Factor Productivity in Turkey. Procedia Economics and Finance, 30, 848-862. https://doi.org/10.1016/S2212-5671(15)01335-0

Shahbaz, M., Wahid, A., Ahmad, K., \& Chaudhary, A. R. (2008). Capital account openness and economic growth nexus: the case study of Pakistan. Journal of Economics and Business, XI(1\&2), 11-33.

Shaw, E. (1973). Financial deepening in Economic Development. Oxford University Press, New York.

Solow, R. (1957). Technical Change and the Aggregate Production Function. The Review of Economics and Statistics, 39(3), 312-320. https://doi.org/10.2307/1926047

Stock, J., \& Watson, M. W. (1993). A simple estimator of cointegrating vectors in higher order integrated systems. Econometrica, 61(4), 783-820. https://doi.org/10.2307/2951763

Vanassche, E. (2004). The impact of international financial integration on industry growth. Manuscript Katholieke Univer-siteite Leuven, Belgium.

Vithessonthi, C., \& Jittima, T. (2012). The impact of capital account liberalization measures. Journal of International Financial Markets, Institutions and Money, 16-34. https://doi.org/10.1016/j.intfin.2011.07.003

\section{Notes}

Note 1. In this paper we use the terms international financial liberalisation, or financial globalisation interchangeably.

Note 2. However, in addition to these potential benefits from opening up to international capital flows, a number of undesirable effects can arise and seriously affect host economies. These adverse effects range from financial contagion to macroeconomic instability (e.g. Reinhart and Reinhart, 2008).

Note 3. The International Monetary Fund and the World Bank.

Note 4. TFP is defined as that part of the increase in production that cannot be attributed to fluctuations in the quantities of factors of production used.

Note 5. Authors' calculations based on UNCTAD data.

Note 6. The West African Economic and Monetary Union (WAEMU) is an area that includes eight countries: Benin, Burkina Faso, Côte d'Ivoire, Guinea-Bissau, Mali, Niger, Senegal and Togo.

Note 7. Foreign direct investment is defined as net investment inflows to acquire a lasting interest (at least $10 \%$ of the share capital) or management control in an enterprise operating in an economy other than that of the investor.

Note 8. Equity portfolio investment flows include net inflows from guarantee funds other than those registered as direct investment and include shares, certificates of deposit and direct purchases of shares on the local stock market by foreign investors.

Note 9. Bond portfolio investment flows are securities issued at fixed interest rates for a period of more than one year. They include net flows through cross-border public and publicly guaranteed and private non-guaranteed bond issues.

Note 10. Multicollinearity only becomes a concern if the correlation coefficient between the variables is greater than 0.8 .

Note 11. See Damodar N. Gujarati, Basic Econometrics, Fourth edition.

Note 12. The results of the FMOLS estimation technique are presented in Appendix A-5. 


\section{Appendix A}

Descriptive Statistics of Variables

\begin{tabular}{llllll}
\hline Variables & Obs. & Mean & Std. Dev. & Min & Max \\
\hline TFP & 35 & 1.095508 & 0.054318 & 1 & 1.215294 \\
\hline Finopen & 35 & 1.611903 & 1.100271 & 0.1761708 & 5.777884 \\
\hline Credsp & 35 & 21.91892 & 8.663367 & 12.4527 & 37.93907 \\
\hline Infl & 35 & 3.828896 & 4.865726 & -0.8058797 & 26.08157 \\
\hline Inv & 35 & 12.94182 & 4.591315 & 4.703723 & 23.48476 \\
\hline Demo & 35 & 2.55 & 0.550994 & 1 & 3 \\
\hline
\end{tabular}

\section{Appendix B}

Correlation Matrix Between Variables

\begin{tabular}{lllllll}
\hline & TFP & Finopen & Credsp & Infl & Inv & Demo \\
\hline TFP & 1.000 & & & & \\
\hline Finopen & 0.0174 & 1.000 & & & & \\
\hline Credsp & 0.2106 & $-0.6146^{*}$ & 1.000 & & & \\
\hline Infl & -0.3233 & 0.0182 & 0.0285 & 1.000 & & \\
\hline Inv & $0.6299 *$ & 0.1825 & -0.0505 & -0.0505 & 1.000 & 1.000 \\
\hline Demo & 0.2795 & -0.1831 & $0.6053^{*}$ & 0.2071 & 0.0190 & 190 \\
\hline
\end{tabular}

Note: $*$ denotes significant correlation coefficients respectively at the $5 \%$ threshold.

Source: Authors' estimates

\section{Appendix C}

Results of the Bounds Test Procedure

\begin{tabular}{llll}
\hline & $\mathrm{k}$ & F-statistic & Decision \\
\hline Equation & 6 & 10.42 & cointegration \\
\hline
\end{tabular}

\section{Appendix D}

Asymptotic Critical Limit Values Tabulated by Pesaran et al (2001) for the F-Statistics

\begin{tabular}{lllll}
\hline & $\begin{array}{l}\text { Number of } \\
\text { regressors (k) }\end{array}$ & Critical thresholds & $\begin{array}{l}\text { Value of the Lower } \\
\text { bound (limit) : I (0) }\end{array}$ & $\begin{array}{l}\text { Value of the Upper } \\
\text { bound (limit) : I (1) }\end{array}$ \\
\hline Equation & 6 & $10 \%$ & 1.99 & 2.94 \\
\hline & $5 \%$ & 2.27 & 3.28 \\
\hline & $1 \%$ & 2.88 & 3.99
\end{tabular}

Source: Pesaran et al, (2001).

Note: The critical values are taken from Table C1. ii: Case 2 (Restricted intercept and no trend) 
Appendix E

\begin{tabular}{lllll}
\hline & $\begin{array}{l}\text { Number of } \\
\text { regressors }(\mathrm{k})\end{array}$ & Critical thresholds & $\begin{array}{l}\text { Value of the Lower } \\
\text { bound (limit) : I (0) }\end{array}$ & $\begin{array}{l}\text { Value of the Upper } \\
\text { bound (limit) : I (1) }\end{array}$ \\
\hline & $10 \%$ & 1.75 & 2.87 \\
\hline Equation & 6 & $5 \%$ & 2.04 & 3.24 \\
\hline & $1 \%$ & 2.66 & 4.05
\end{tabular}

Note: The critical values are taken from Table C1. i: Case 1 (no intercept and no trend)

\section{Appendix F}

Result of Regressions Using the FMOLS Method

\begin{tabular}{lllll}
\hline Variables & Coefficient & Std. Error & t-statistic & Prob. \\
\hline Finopen & 0.0109 & 0.0056 & 1.9528 & 0.0609 \\
\hline Credsp & 0.0034 & 0.0009 & 3.6753 & 0.0010 \\
\hline Infl & -0.0039 & 0.0009 & -3.9546 & 0.0005 \\
\hline Inv & 0.0099 & 0.0010 & 9.2051 & 0.0000 \\
\hline Demo & 0.0056 & 0.0118 & 0.4811 & 0.6342 \\
\hline Constant & 0.8730 & 0.0289 & 30.1352 & 0.0000 \\
\hline R-squared & & 0.665 & & \\
\hline Adjusted R-squared & & 0.606 & & \\
\hline
\end{tabular}

Source: Author's estimate under Eviews 9.0

\section{Copyrights}

Copyright for this article is retained by the author(s), with first publication rights granted to the journal.

This is an open-access article distributed under the terms and conditions of the Creative Commons Attribution license (http://creativecommons.org/licenses/by/4.0/). 